\title{
PENERAPAN METODE ROLE PLAYING DENGAN MEDIA ORKAS (ORGAN KORAN BEKAS) UNTUK MENINGKATKAN PRESTASI BELAJAR BIOLOGI SISWA KELAS XI IPA MADRASAH MA'ARIF AL-FALAH
}

\author{
Sri Utami ${ }^{1}$, Indah Wijianti ${ }^{2}$, Muh. Waskito Ardhi ${ }^{3}$ \\ ${ }^{1,2,3)}$ Program Studi Pendidikan Biologi FPMIPA, IKIP PGRI MADIUN \\ Jalan Setia Budi No. 85 Madiun \\ email: ${ }^{1)}$ sriutami31@yahoo.co.id \\ Diterima 10 Agustus 2016, Disetujui 30 September 2016
}

\begin{abstract}
This study aims to determine the application of methods Role Playing with "Orkas (Organ Koran Bekas)" can improve learning achievement of XI IPA Biology class in Madrasah Maarif Al-Falah. The research was conducted in Madrasah Maarif AL-Falah district of Ngrayun Ponorogo. The subjects were students of class XI second half of Al-Falah Madrasah Maarif District of Ngrayun Ponorogo school year 2014/2015 the number of students 16 children. The study consisted of two cycles, each cycle consisting of four phases: planning, implementation, observation and reflection. The results showed an increase in learning achievement. Student achievement can be seen in the first cycle of 74.75, while the second cycle of 79.43 increased by 4.68. Additionally methods and media Orkas Role Playing (Organ newspaper Used) can improve the quality of the learning process. This is evident from the increasing every aspect of students' courage and precision in playing its role 50\% (18.75\% to 68.75\%). Cooperation of students in the group increased by $50 \%$ (25\% to $75 \%)$. Attitude and cooperation skills of students in the group during the role play increased $37.5 \%$ (31.25\% to $68.75 \%)$. And courage of students in expressing responses or opinions and experience after playing the role of increased $37.5 \%$ (31.25\% to $68.75 \%)$. It can be concluded that the use of Role Playing methods and media Orkas Organ Koran Bekas/Organs From Newspaper) can increase student achievement grade XI Madrasah Maarif Al-Falah.
\end{abstract}

Keywords: Role Playing, Orkas (Organ Koran Bekas), Student achievement

\section{PENDAHULUAN}

Ditinjau dari tujuan pendidikan bangsa, mata pelajaran Biologi bertujuan untuk: (1) Membentuk sikap positif terhadap biologi dengan menyadari keterraturan, keindahan alam, serta mengagungkan kebesaran Tuhan Yang Maha Esa. (2) Memupuk sikap ilmiah yaitu jujur, objektif, terbuka, ulet, kritis dan dapat bekerjasama dengan orang lain. (3) Mengembangkan pengalaman untuk dapat mengajukan dan menguji hipotesis melalui percobaan, serta mengkomunikasikan hasil percobaan secara lisan dan tertulis. (4) Mengembangkan kemampuan berfikir analitis, induktif, dan deduktif dengan menggunakan konsep dan prinsif Biologi. (5) Mengembangkan penguasaan konsep dan prinsip Biologi dan saling keterkaitannya dengan IPA lainnya serta mengembangkan pengetahuan, keterampilan dan sikap percaya diri. (6) Menerapkan konsep dan prinsip biologi untuk menghasilkan karya teknologi sederhana yang berkaitan dengan kebutuhan manusia. (7) Meningkatkan kesadaran dan berperan serta dalam menjaga kelestarian lingkungan.

Proses pembelajaran di Madrasah Ma'arif Al-Falah belum mencapai karakteristik dan tujuan pendidikan di atas. Oleh karena itu sekolah mencanangkan pembelajaran yang lebih inovatif dan menyenangkan serta mengubah suasana pembelajaran yang masih berpusat pada 
guru sebagai sumber informasi utama menjadi guru sebagai fasilitator. Metode pembelajaran ceramah yang selama ini menjadi pilihan utama dalam proses pembelajaran, dianjurkan untuk diganti atau dipadukan dengan metode atau model yang lain sehingga seringkali proses belajar sesuai dengan yang diharapkan. Kondisi Kegiatan belajar mengajar (KBM) yang monoton dan membosankan diharapkan berubah menjadi menyenangkan. Siswa yang pasif ketika mengikuti kegiatan pembelajaran diharapkan berubah menjadi aktif baik dalam diskusi maupun kegiatan KBM yang lain. Siswa yang semula hanya membaca, menulis, mendengarkan, dan menghafal menjadi berperan langsung/melakukan penemuan-penemuan konsep dalam KBM. Prestasi belajar siswa yang masih dibawah KKM 75 diharapkan dapat naik melebihi KKM. Maka diperlukan sebuah model pembelajaran yang lebih memberdayakan potensi siswa dan membuat siswa aktif, sehingga dapat mengubah proses pembelajaran yang berpusat pada guru menjadi berpusat pada siswa yang memberikan dampak positif pada potensi dan kompetensi siswa.

Berdasarkan pada pokok permasalahan diatas, ditawarkan solusi dengan menerapkan metode Role Playing dengan media Orkas (Organ Koran Bekas). Orkas (Organ koran bekas) digunakan dalam metode pembelajaran Role Playing dianggap paling tepat untuk kondisi siswa Madrasah Ma'arif Al-falah karena bahan pembuatannya mudah dicari, para siswa dapat membuat sendiri. Selain itu dengan media Orkas (Organ koran bekas) diharapkan proses pembelajaran menjadi tidak monoton atau membosankan, lebih menarik serta meningkatkan prestasi belajar siswa. Seperti yang dijelaskan dalam penelitian Sumarni, (2014) menyimpulkan bahwa terdapat pengaruh yang signifikan antara penggunaan metode role playing terhadap hasil pembelajaran. Menurut Hamalik (2014) metode mengajar Role Playing mempunyai beberapa keuntungan yaitu pada waktu dilaksanakannya bermain peran, siswa dapat bertindak dan mengekspresikan perasaan dan pendapat tanpa kekhawatiran mendapat sanksi. Bermain peran merupakan suatu cara penguasaan materi pembelajaran melalui pengembangan imajinasi yang dilakukan siswa dengan memerankannya sebagai tokoh hidup atau benda mati. Permainan ini biasanya dilakukan lebih dari satu orang, hal tersebut bergantung dari apa yang diperankan.

\section{METODE}

Penelitian dilaksanakan selama 6 bulan yaitu Februari sampai Juli 2015 di Madrasah Ma'arif Alfalah, Kecamatan Ngrayun Kabupaten Ponorogo, yang beralamat di Jalan Surontanen nomor 06 Desa Baosan Lor, Ngrayun, Ponorogo. Jenis penelitian adalah penelitian tindakan kelas dengan pendekatan fenomenologis (phenomenological approach.). Menurut Hamalik (2014) fenomena artinya gejala pandangan, fenomenologis melihat segala sesuatu dari gejala yang ada. Subyek penelitian terbatas pada siswa kelas XI IPA, dengan jumlah siswa 16 orang ( 6 siswa lakilaki dan 10 siswa perempuan). Kondisi kemampuan belajar siswa rata-rata normal, dan tidak ada siswa yang kemampuannya dibawah normal. Teknik pengumpulan data dengan menggunakan teknik tes dan observasi. Teknik tes digunakan untuk mengetahui prestasi belajar siswa. Teknik observasi digunakan untuk mengetahui Keberanian dan ketepatan siswa dalam memainkan perannya, kerjasama siswa dalam kelompok, sikap dan Keberanian siswa dalam mengemukakan tanggapan atau pendapat dan pengalaman setelah melakukan bermain peran, serta keterlaksanaan proses pembelajaran 
menggunakan metode Role Playing dengan media Orkas.

Penelitian menggunakan rancangan penelitian tindakan kelas (Classrom action research) yang berusaha mengkaji dan merefleksikan secara mendalam beberapa aspek dalam kegiatan belajar mengajar, yaitu perfomance guru, interaksi guru-siswa interaksi antar siswa untuk menjawab permasalahan penelitian. Penelitian menggunakan dua siklus belajar yang disesuaikan dengan materi yang pilih. Masing-masing siklus terdiri dari empat tahapan pelaksanaan tindakan kelas yang meliputi: Perencanaan tindakan, Pelaksanaan tindakan, Observasi (pengamatan), Refleksi.

Tabel 1. Indikator Keberhasilan Proses Pada Siklus I dan II.

\begin{tabular}{|c|c|c|c|}
\hline No & Aspek & Pencapaian & Cara Mengukur \\
\hline 1 & $\begin{array}{l}\text { Keberanian dan ketepatan siswa } \\
\text { dalam memainkan perannya }\end{array}$ & $25 \%$ & $\begin{array}{l}\text { - Diamati ketika pembelajaran berlangsung } \\
\text { - Ditulis pada lembar pengamatan oleh } \\
\text { peneliti } \\
\text { - Dihitung dari jumlah siswa yang aktif } \\
\text { bermain peran dibagi jumlah keseluruhan }\end{array}$ \\
\hline 2 & $\begin{array}{l}\text { Kerjasama siswa dalam } \\
\text { kelompok }\end{array}$ & $25 \%$ & $\begin{array}{l}\text { - Diamati ketika pembelajaran berlangsung } \\
\text { - Ditulis pada lembar pengamatan. } \\
\text { - Kerjasama dan tanggung jawab antar } \\
\text { pemain dibagi jumlah siswa }\end{array}$ \\
\hline 3 & $\begin{array}{l}\text { Sikap dan kemampuan } \\
\text { kerjasama siswa dalam } \\
\text { kelompok selama melakukan } \\
\text { bermain peran }\end{array}$ & $25 \%$ & $\begin{array}{l}\text { - Siswa yang aktif saat pembelajaran } \\
\text { berlangsung dibagi jumlah keseluruhan }\end{array}$ \\
\hline 4 & $\begin{array}{l}\text { Keberanian siswa dalam } \\
\text { mengemukakan tanggapan atau } \\
\text { pendapat dan pengalaman } \\
\text { setelah melakukan bermain } \\
\text { peran }\end{array}$ & $25 \%$ & - Kreatifitas siswa dibagi jumlah siswa \\
\hline
\end{tabular}

Sumber: (Indrawati, 2013)

Data dianalisis secara deskriptif kualitatif dengan rumuskan oleh peneliti sebagai berikut:

$$
\text { Nilai }=\frac{\text { jumlah siswa yang aktif }}{\text { jumlah seluruh siswa }} \times 100 \%
$$

Tingkat keberhasilan:

$\begin{array}{ll}>80 \% & \text { : Sangat Tinggi } \\ \%-79 \% & \text { : Tinggi } \\ 40 \%-59 \% & : \text { Sedang } \\ 20 \%-39 \% & \text { : Rendah } \\ <20 \% & \text { : Sangat Rendah, }\end{array}$

Sumber: Purwanto (dalam Giarthy, Dkk. 2013). 


\section{HASIL DAN PEMBAHASAN}

\section{a) Keterlaksanaan Pembelajaran dengan metode Role Playing dan media Orkas (Organ Koran Bekas).}

Keterlaksanaan pembelajaran dengan metode Role Playing dan media Orkas (Organ Koran Bekas) yang dilaksanakan pada siklus I dan siklus II terjadi peningkatan keefektifan waktu. Adapun peningkatan tersebut terbukti karena siswa sudah bisa memanfaatkan waktu yang diberikan dengan baik dan siswa sudah bisa menentukan hal-hal apa saja yang diperlukan dan tidak diperlukan dalam penerapan metode Role Playing, sehingga dapat menggunakan waktu sebaik mungkin.

Hal tersebut selaras dengan penelitian dari Sumarni (2014) tentang penggunaan metode Role Playing memberikan pengaruh yang tinggi terhadap hasil pembelajaran.

\section{b) Aktivitas Siswa dalam Pembelajaran dengan metode Role Playing dan media Orkas (Organ Koran Bekas)}

Dari data diatas, dapat diketahui bahwa terjadi peningkatan aktivitas siswa dalam pembelajaran dengan metode Role Playing dan media Orkas (Organ Koran Bekas) pada siklus I dan Siklus II.

Hal tersebut selaras dengan penelitian Dita dkk., (2014) tentang penerapan metode Role Playing dalam pembelajaran tematik dapat meningkatkan aktivitas dan hasil belajar siswa.

Berikut adalah perbandingan peningkatan aktivitas siswa dalam kategori baik dengan metode Role Playing dan media Orkas, dapat dilihat pada tabel 2 .

Tabel 2. Perbandingan Hasil Pengamatan Aktivitas Siswa Menggunakan metode Role Playing dan media Orkas (Organ Koran Bekas) Kategori Baik

\begin{tabular}{|c|c|c|c|}
\hline No & Aspek yang diamati & Siklus I & Siklus II \\
\hline 1. & $\begin{array}{l}\text { Keberanian dan ketepatan siswa dalam memainkan } \\
\text { perannya }\end{array}$ & \begin{tabular}{c|}
3 \\
$18,75 \%$ \\
\end{tabular} & $\begin{array}{c}11 \\
68,75 \% \\
\end{array}$ \\
\hline 2. & Kerjasama siswa dalam kelompok & $\begin{array}{c}4 \\
25 \% \\
\end{array}$ & $\frac{12}{75 \%}$ \\
\hline 3. & $\begin{array}{l}\text { Sikap dan kemampuan kerjasama siswa dalam kelompok } \\
\text { selama melakukan bermain peran }\end{array}$ & $\begin{array}{c}5 \\
31,25 \% \\
\end{array}$ & $\frac{11}{68,75 \%}$ \\
\hline 4. & $\begin{array}{l}\text { Keberanian siswa dalam mengemukakan tanggapan atau } \\
\text { pendapat dan pengalaman setelah melakukan bermain } \\
\text { peran }\end{array}$ & $\begin{array}{c}5 \\
31,25 \%\end{array}$ & $\frac{11}{68,75 \%}$ \\
\hline
\end{tabular}

Hasil pengamatan yang dilaksanakan pada siklus I dan siklus II pada mata pelajaran Biologi pokok bahasan sistem pencernaan manusia kelas XI IPA semester 2 (dua) dengan menggunakan metode Role Playing dengan menggunakan media Orkas (Organ Koran Bekas) menunjukan terjadi peningkatan. Peningkatan tersebut dijelaskan sebagai berikut:
1. Keberanian dan ketepatan siswa dalam memainkan perannya yang awalnya hanya 3 orang atau $18,75 \%$ meningkat menjadi 11 orang atau 68,75 \% . Peningkatan tersebut dikarenakan:
a) Siswa tidak malu lagi dalam memainkan peran. 
b) Siswa tidak ragu lagi dalam memainkan peran menggunakan media Orkas (Organ Koran Bekas)

2. Kerjasama siswa dalam kelompok pada siklus I yang awalnya 4 orang atau $25 \%$ meningkat menjadi 12 orang atau $75 \%$. Peningkatan tersebut dikarenakan:

a) Siswa sudah bisa menggunakan media Orkas (Organ Koran Bekas) dengan baik, sehingga terjadi kekompakkan.

b) Siswa sudah bisa bertanggung jawab atas peran yang dibebankan kepadanya sehingga dapat terlaksana dengan baik.

3. Sikap dan kemampuan kerjasama siswa dalam kelompok selama melakukan bermain peran yang awalnya hanya 5 siswa atau $31,25 \%$ meningkat menjadi 11 siswa atau $68,75 \%$. Peningkatan tersebut dikarenakan:

a) Siswa sudah bisa menggunakan media Orkas (Organ Koran Bekas) dengan baik dan benar.

b) Siswa sudah bisa menggunakan logat bicara sesuai dengan karakter yang diperankannya.

4. Keberanian siswa dalam mengemukakan tanggapan atau pendapat dan pengalaman setelah melakukan bermain peran yang awalnya 5 siswa atau 31,25\% meningkat menjadi 11 siswa atau 68,75\%. Peningkatan tersebut dikarenakan:

a) Siswa mampu menyebutkan fungsi dari masing-masing alat sistem pencernaan pada manusia, sesuai dengan bagian media Orkas (Organ Koran Bekas) yang telah diperankan.

b) Siswa mampu mengembangkan cerita yang berbeda, namun sesuai dengan materi yang diajarkan

5. Efektifitas pemanfaatan waktu sudah sesuai dengan rencana pembelajaran. Peningkatan tersebut dikarenakan: a) Siswa sudah bisa memanfaatkan waktu yang diberikan dengan baik.

b) Siswa sudah bisa menentukan hal-hal apa saja yang diperlukan dan tidak diperlukan dalam penerapan metode Role Playing, sehingga dapat menggunakan waktu sebaik mungkin.

Adapun hambatan dalam menggunakan metode Role Playing dengan media Orkas (Organ Koran Bekas) adalah sebagai berikut:

1) Pembuatan media yang rumit memakan banyak waktu dan sekali pakai.

2) Siswa belum terbiasa menggunakan metode Role Playing dengan media Orkas (Organ Koran Bekas).

3) Siswa belum bisa mengaitkan antara materi pelajaran dengan situasi kehidupan sehari-hari.

4) Pemanfaatan waktu belum sesuai dengan rencana.

\section{c) Data Prestasi Belajar Siswa (Nilai Kongnitif ) dengan metode Role Playing dan media Orkas (Organ Koran Bekas)}

Pada nilai ulangan harian yang telah dilaksanakan pada siklus I dan siklus II terjadi peningkatan prestasi belajar siswa. Temuan-temuan diatas tentang penggunaan metode Role Playing dengan media Orkas (Organ Koran Bekas) selaras dengan penelitian Gusmaweti (2014) mengemukakan peningkatan hasil belajar biologi aspek afektif, aspek kongnitif dan aspek psikomotor dengan menggunakan model pembelajaran Role Playing pada pembelajaran biologi mahasiswa program studi Pendidikan Biologi FKIP Universitas Bung Hatta.

Berikut adalah perbandingan peningkatan prestasi belajar siswa dengan metode Role Playing dan media Orkas, dapat dilihat pada tabel 3 . 
Tabel 3. Perbandingan Nilai Ulangan Harian Siswa Menggunakan metode Role Playing dan media Orkas (Organ Koran Bekas) Siklus I dan Siklus II.

\begin{tabular}{llccc}
\hline No & Nama Siswa & Nilai Siklus I & Nilai Siklus II & Keterangan \\
\hline 1 & Ardhita Yesi A. & 76 & 80 & Meningkat \\
\hline 2 & Depi Nuraini & 78 & 80 & Meningkat \\
\hline 3 & Diah Sulvita & 80 & 85 & Meningkat \\
\hline 4 & Hepi Nuryani & 73 & 75 & Meningkat \\
\hline 5 & Irfan Riskiono & 85 & 90 & Meningkat \\
\hline 6 & Ita Aprilia & 73 & 73 & Tetap \\
\hline 7 & Joko Lasmono & 65 & 75 & Meningkat \\
\hline 8 & Lina Tri A. & 70 & 75 & Meningkat \\
\hline 9 & Maryono Alif U. & 70 & 76 & Meningkat \\
\hline 10 & Muh. Ma'ruf & 75 & 78 & Meningkat \\
\hline 11 & Nova Eko A. & 85 & 90 & Meningkat \\
\hline 12 & Nufitri Hefika & 70 & 78 & Meningkat \\
\hline 13 & Nurul Hidayah & 75 & 83 & Meningkat \\
\hline 14 & Tri Wahyuni & 70 & 75 & Meningkat \\
\hline 15 & Vina Aprilia M. & 76 & 78 & Meningkat \\
\hline 16 & Yusuf Nugroho & 75 & 80 & Meningkat \\
\hline & Rata-rata & $\mathbf{7 4 , 7 5}$ & $\mathbf{7 9 , 4 3}$ & \\
\hline & \% Ketuntasan & $\mathbf{5 6 , 2 5 \%}$ & & \\
\hline
\end{tabular}

Pada tabel diatas tampak bahwa nilai rata-rata ulangan harian pada siklus I yaitu 74,75 dan prosentase ketuntasan $56,25 \%$ belum mencapai ketuntasan klasikal/ nilai rata-rata kelas dan masih dibawah KKM (75). Pada siklus II sudah mencapai KKM yaitu meningkat menjadi 79,43 dan prosentase ketuntasan mencapai $87,5 \%$ sudah melebihi $75 \%$.

Peningkatan tersebut terjadi karena:

a) Siswa sudah mulai menyukai metode Role Playing dengan menggunakan media Orkas (Organ Koran Bekas) karena sudah mulai memahaminya dalam memeragakan.

b) Kegiatan pembelajaran dikelas menjadi lebih menarik dan tidak monoton.
Adapun hambatan menggunakan teknik tes (ulangan harian) adalahsebagai berikut:

a) Siswa tidak jujur (mencontek jawaban siswa lain) dalam mengerjakan soal

b) Siswa tidak belajar

Hasil pelaksanaan penelitian pada setiap siklus, dengan menggunakan metode Role Playing dan media Orkas (Organ Koran Bekas) untuk meningkatkan prestasi belajar siswa rata-rata hasil tindakan pada siklus I dengan nilai rata-rata ulangan harian 74,75 dan siklus II dengan nilai rata-rata 79,43 meningkat 4,68. Adapun histogram peningkatan prestasi belajar siswa dapat dilihat pada gambar 4.1. 


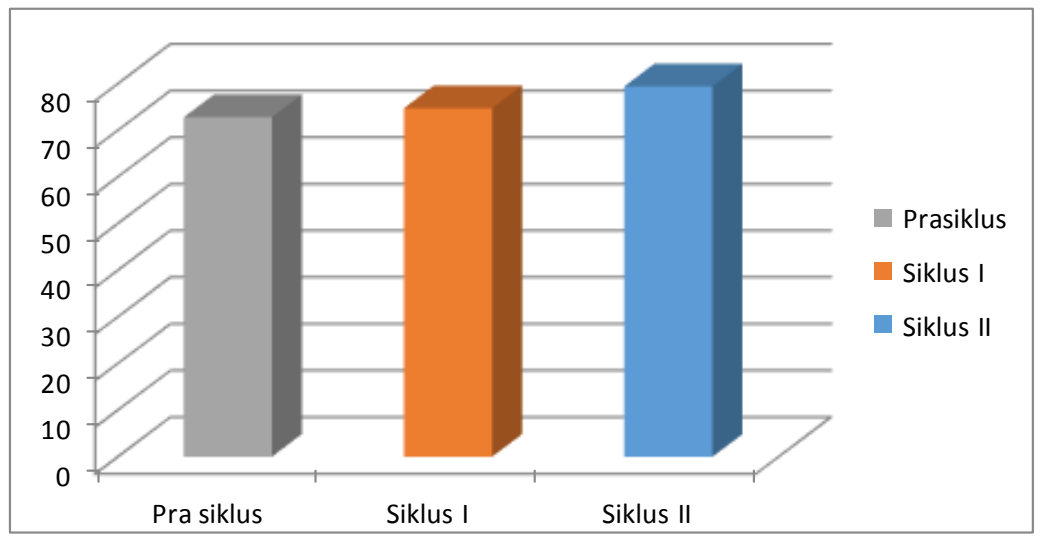

Gambar 1. Histogram Rata-Rata Prestasi Belajar Siswa

Peningkatan prestasi belajar Biologi dapat dibuktikan dengan siswa menyukai metode Role Playing dengan media Orkas (Organ Koran Bekas) karena siswa bisa memahaminya dalam memeragakan, serta pembelajaran menjadi lebih menarik dan tidak monoton.

Berdasarkan hasil pengamatan memainkan peran dari tabel siklus I dan siklus II secara klasikal mengalami banyak peningkatan aktivitas siswa. Hal tersebut terbukti dari meningkatnya tiap aspek diataranya: Keberanian dan ketepatan siswa dalam memainkan perannya meningkat $50 \%$ (18,75\% menjadi 68,75\%). Kerjasama siswa dalam kelompok meningkat 50\% (25\% menjadi 75\%). Sikap dan kemampuan kerjasama siswa dalam kelompok selama melakukan bermain peran meningkat $37,5 \%$ (31,25\% menjadi 68,75\%). Dan Keberanian siswa dalam mengemukakan tanggapan atau pendapat dan pengalaman setelah melakukan bermain peran meningkat $37,5 \%$ (31,25\% menjadi 68,75\%).

Peningkatan aktivitas siswa dalam memainkan peran dapat dibuktikan dengan Siswa sudah memahami metode pembelajaran Role Playing dan media Orkas (Organ Koran Bekas). Hal tersebut terbukti ketika siswa memainkan perannya sesuai dengan karakter tokoh dalam wacana. Siswa termotivasi untuk belajar dan antusias untuk mengikuti pembelajaran. Hal tersebut terbukti sudah tidak ada lagi siswa yang bermain sendiri serta fokus dalam pelajaran. Siswa tidak malu dan tidak ragu untuk memainkan perannya. Hal tersebut terbukti ketika siswa memainkan perannya dengan percaya diri dan tidak ada lagi siswa yang cengegesan. Pembelajaran menjadi menarik dan tidak monoton serta pemanfaatan waktu sudah sesuai rencana. 


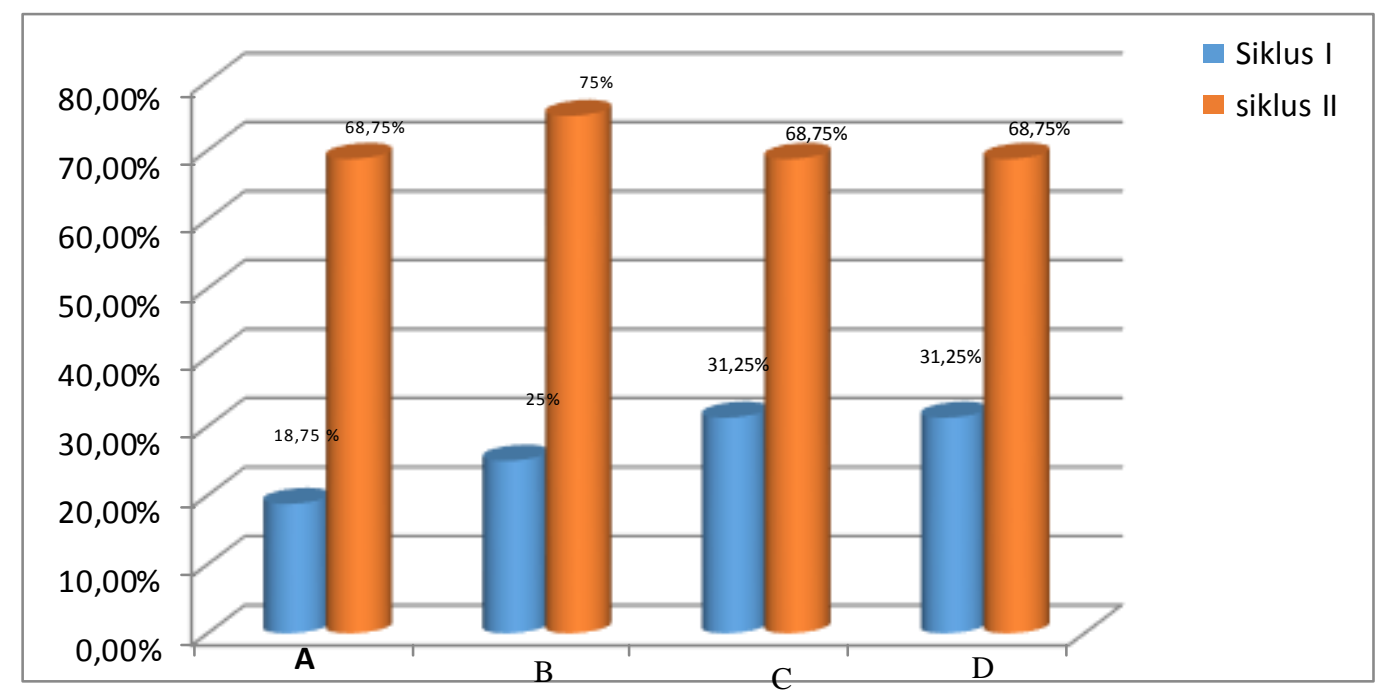

Gambar 4.2. Histogram rata-rata aktivitas siswa, Keterangan : A: Keberanian dan ketepat - an siswa memainkan perann B: Kerjasama siswa, C: Sikap dan kemampuan kerjasama siswa, D:Keberanian menyampaikan pendapat

\section{SIMPULAN}

Penggunaan metode Role Playing dan media Orkas (Organ Koran Bekas) dapat meningkatan prestasi belajar siswa mata pelajaran Biologi. Hal tersebut terbukti pada siklus I sebesar 74,75 mengalami peningkatan pada akhir siklus II sebesar 79,43 serta dapat menjadikan kegiatan belajar mengajar menjadi lebih menarik dan tidak monoton. Keaktifan siswa dalam memainkan peran dapat meningkatkan kualitas proses pembelajaran, karena dari tiap aspek yang diamati meningkat hingga mencapai $50 \%$.

\section{DAFTAR PUSTAKA}

Amri, S. (2013). Pengembangan dan Model Pembelajaran dalam Kurikulum 2013. Jakarta: Prestasi Pustakarya.

Arifin, Z. (2009). Evaluasi Pembelajaran Prinsif Teknik Prosedur. Jakarta: Rosda.

Arikunto, S. (2006). Prosedur Penelitian Suatu Pendekatan Praktek. Jakarta: Rhineka Cipta.
Dita, Dkk. (2014). Pengaruh metode Role Playing terhadap hasil pembelajaran PKN siswa kelas V Sekolah Dasar.

Gusmaweti, (2014). Model pembelajaran Role Playing untuk meningkatkan hasil belajar biologi siswa FKIP Universitas Bung Hatta. Artikel Seminar Nasional XI Pendidikan FKIP UNS.

Hamalik, O. (2014). Proses Belajar Mengajar. Jakarta: Bumi Aksara.

Hamzah, Dkk. (2014). Belajar dengan Pendekatan Pembelajaran Aktif Inovatif Lingkungan Kreatif Efektif Menarik. Jakarta. Bumi Aksara.

Huda, M. (2011). Model-model Pengajaran dan Pembelajaran. Malang: Pustaka Pelajar.

Muntamah. (2011). Peningkatan Minat Belajar IPS dengan Metode Bermain Peran Siswa Kelas II Semester II SDN Tapelan 03 Kecamatan Ngraho Kabupaten Ponorogo Tahun Pelajaran 2011. Tesis tidak diterbitkan. Madiun: Pendidikan Guru Sekolah Dasar. IKIP PGRI Madiun.

Ningsih, F. (2008). Peningkatan Prestasi Belajar Siswa Melalui Penggunaan Media Gambar (Pictural) dalam 
Mata Pelajaran IPS dengan Pokok Bahasan Peta Pembagian Wilayah di Indonesia pada Siswa Kelas VI SDN Prigi IIKecamatan Kanor Kabupaten Bojonegoro. Tesis tidak diterbitkan. Madiun: Pendidikan Guru Sekolah Dasar. IKIP PGRI Madiun.

Sanjaya, W. (2009). Perencanaan dan Desain Sistem Pembelajaran. Jakarta: Kencana Prenada Media Group.

Sriwidarti. (2014). Pengaruh Pembelajaran dengan Strategi Inkuiri Terhadap Prestasi Belajar IPS Siswa Kelas VI SDN 4 Baosan Lor Kecamatan Ngrayun Kabupaten Ponorogo Tahun Pelajaran 2014-2015. Tesis tidak diterbitkan. Madiun: Pendidikan Guru Sekolah Dasar. IKIP PGRI Madiun.
Sukmadinata, S. (2005). Landasan Psikologi Proses Pendidikan. Bandung: PT Remaja Rosdakarya.

Sumarni, Dkk. (2014). Pengaruh Metode Role Playing Terhadap Hasil Pembelajaran PKN Siswa Kelas V Sekolah Dasar. Artikel Pendidikan, 1 (1): 1-13.

Susilana dan Riyana. (2008). Media Pembelajaran. Bandung: CV Wacana Prima

Tresnoningsih, S. (2013). Pemanfaatan Barang Bekas (Rongsok) untuk Menunjang Inovasi Pembelajaran Matematika. 14 (2): 1-10.

Uno, B. (2014). Model Pembelajaran. Jakarta: Bumi Aksara. 